e-ISSN: 2721-3013, p-ISSN: 2721-3005

DOI: https://doi.org/10.38035/jafm.v1i1

Received: 9 February 2020, Revised: 22 Ferbruary, Publish: 8 March 2020

https://creativecommons.org/licenses/by/4.0/

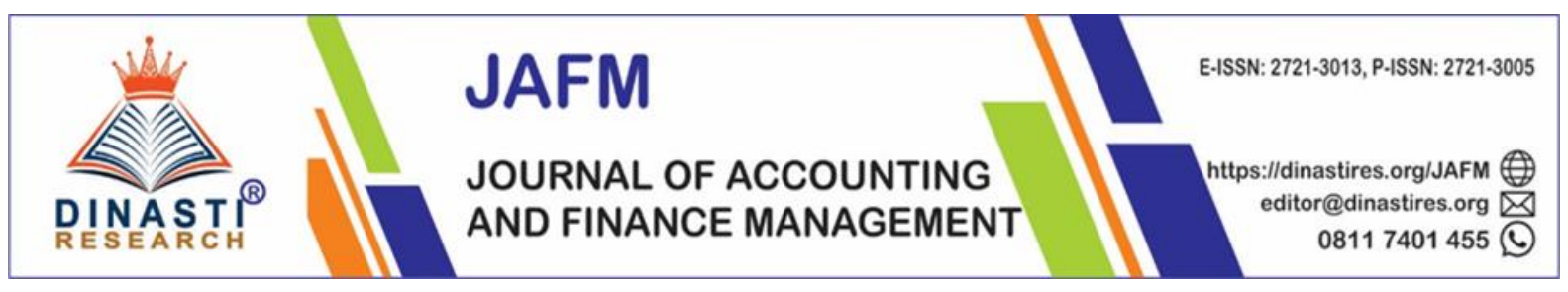

\title{
Corporate Social Responsibility, Social and Community Development Program as the Implementation of Gcg at PT PLN (Persero)
}

\author{
Surya Fitriadi \\ Universitas Mercubuana, Jakarta, Indonesia, surya_fitriadi@yahoo.com \\ Corresponding Author: Surya Fitriadi
}

\begin{abstract}
The implementation of the Corporate Social Responsibility (CSR) program is one implementation concept of good corporate governance. Good corporate governance regulates the relationships of all stakeholders that can be fulfilled proportionally, avoid mistakes in corporate strategy and ensures that mistakes can be corrected immediately. PT. PLN (Persero) is a State- Owned Company (BUMN), a company engaged in the electric energy has a commitment to improve the quality of people's lives through electricity and make electricity as a driving force for economic activities and environmentally sound businesses. PLN business objectives will be achieved if the Company is able to maintain a balance of economic, social and environmental performances. The obtained economic value is eligible for the benefits of the community, the environment, employees and customers, through quality and sustainable social and environmental responsibility programs Social responsibility programs that meet people's needs, improve living standards and expand employment opportunities, positive interaction between PLN and the community will increase their sense of belonging and help maintain PLN installations in their residential areas.
\end{abstract}

Keywords: Corporate Social Responsibility (CSR), Community Development Program

\section{INTRODUCTION}

CSR is the core of business ethics which is now being considered by the company in maintaining its existence. Managements think more realize that the company's goals are not solely achieved through growth and profit. But CSR is also needed to support the company's success in order to survive and develop in the future. These will trigger the company to increase excellence and be integrated with the surrounding environment. Rising the company's image will increase financial performance and should be more attractive to investors.

The concept of CSR aims to increase the productive activities of the community through assistance by the companies. The assistance is expected to be developed on an 
ongoing basis in various fields. Increasing public trust from both consumers and business partners will ultimately become the company's achievements in the form of image and reputation.

The company's business sustainability will grow with one choice, namely aligning the achievement of profit performance (Profit), with social performance (People), and environmental performance (Planet) on an ongoing basis according to Elkington (1997) in Lako (2011). The opinion is intended that the company does not only focus on profits, but also responsibility for the impact of activities and the company's social environmental conditions.

Corporate Social Responsibility (CSR) is a continuing commitment of the business world to take responsibility for the negative impacts they cause and to prevent negative impacts not harming society and the environment.

As the only company engaged in electricity for the community, electricity is very influential on the livelihoods of the people of Indonesia. CSR activities will be very beneficial to enhance the positive image in the eyes of the community and awaken public trust in the company.

\section{LITERATURE REVIEW}

The definition of CSR according to The World Business Council for Sustainable Development is a continuing commitment from business people to act ethically and to contribute to economic development while improving the quality of life for workers and their families, as well as for local communities and society in general. Berampu (2015)

From the above definition, we see the importance of CSR programs carried out continuously (sustainability) so that it gives long-term effects for the community around the company. Providing assistance only once has no significant impact. The form of CSR programs can vary, including the provision of scholarships for children of poor families, maintenance of public facilities, improvement of welfare and improvement of the environment, donations for events in villages with a social community.

Corporate Social Responsibility (CSR) is part of the company's strategy in meeting the needs and interests of its stakeholders. Awareness of the company's long-term sustainability makes CSR programs an important part of the company's strategy in addition to profit. In business, company management has the responsibility to bring profit to shareholders by managing the company in accordance with applicable law, on the other hand the company has obligations in the form of morals and ethics (Nurjihad and Ali, 2020).

The traditional view places the responsibility of company management solely on its owners or shareholders. Changes to a wider perspective make CSR a corporate obligation to the wider community including employees, consumers, business partners and the local community and the Government. Law number 40 of 2007 concerning Limited Liability Companies chooses to use the term Social and Environmental Responsibility for the elaboration in the regulation. At this time there is no language unity for the term CSR but conceptually everything has the same meaning.

Corporate Social Responsibility (CSR) is a process of integrating community care in daily business operations through coordination with stakeholders based on voluntary principles and partnerships. Corporate CSR is expected to be a commitment to make a longterm contribution to the issues that develop in the community so that it can create harmonious relationships for the environment.

According to Kartini (2013) Corporate Social Responsibility (SCR) is the commitment of the company or the business world to contribute to sustainable economic development by paying attention to corporate social responsibility and emphasizing the balance between attention to economic, social and environmental aspects. 
The complex social problems that have occurred lately due to the high poverty rate have caused CSR programs to be expected to be a concept that can provide a breakthrough alternative to reducing poverty through community empowerment to improve their welfare.

According to Elkingston (1999) in Fitri (2015) stated that a company that shows that a company that shows social responsibility will pay attention to improving the quality of the company (profit); community, especially the surrounding community (people); and the environment (planet earth).

Triple Bottom Line with 3P, namely:

1. Profit that supports corporate profits

2. People who improve community welfare

3. A planet that improves the quality of society.

According to Kasali (2007) states that social responsibility has a strategic content in supporting the construction of corporate strategies to realize competitive advantage. Furthermore, social responsibility activities can be packaged in coloring various forms of concern for stakeholders in promotion, which is enough to break the construction of corporate strategies that have been around for so long.

Social responsibility has a social message and attention to the environment and development in the future. This is in line with the opinion where the companies need to be open to the social activities that have been carried out. The company's social activities are the legitimacy of the existence of the company by all stakeholders, including the consumers and the market, in the long run. CSR is part of business operations and is a commitment to improving the economy and socially in a sustainable, holistic and institutionalized manner in addition to increasing profits for shareholders.

Implementation of CSR programs can be categorized according to the needs of the company and the objectives of the company's CSR. According to Kotler and Lee (2006) (in Kartini, 2013) there are six types of CSR programs that companies can choose by considering company goals, types of program excellence, potential benefits to be gained, namely:

1. Cause Promotion

This type of program is a CSR program by providing a number of funds or otherresources to increase public awareness of an issue of social problems or to raise funds from the community including work partners or in the context of recruiting volunteers for certain activities.

2. Cause Related Marketing

This CSR program is in the form of a company's commitment to make a contribution, the amount of which is taken from a certain percentage of revenue or the amount of sales of a particular product.

3. Corporate Social Marketing

This program is carried out by developing or conducting campaigns to change the behavior of people who are not good to improve health, safety, preserve the environment, and improve the welfare of the community. This social coporate marketing campaign focuses on behavioral changes related to health issues, protection against accidents, the environment and community involvement.

4. Corporate Philanthtopy

In this program the company gives direct donations in the form of grants to certain communities. These donations are in the form of cash, aid packages and services free of charge. Coporate philanthropy is related to the priority of corporate attention to the interests of social problems that occur.

5. Community Volunteering

This program is the company's support for all company partners including employees to 
play an active role willingly and willingly to help community groups around the company and environmental targets of the program.

6. Socially Responsible Business Practice

Business practices in which companies make investments that support solving a social problem to improve community welfare and preserve the environment.

So far, many of the company's CSR funds are not on target because they do not have a positive impact on society. CSR is more often interpreted as giving money for social activities, building bridges and others. As a result there is no learning process or empowerment to improve the economic life of the community. Companies should conduct a comprehensive mapping of what the community needs in a particular location so that CSR can be allocated to programs that can empower the community and not programs in the form of grants or assistance that are directly used up. Thus, the people's economy can develop and improve independently so that one day CSR assistance can be diverted to other community development.

For example, in a coastal area that has the potential of a fishpond business, the company must conduct training in pond management from the process of opening the pond, breeding to harvest and its economic aspects. The company prepares instructors for education, capital for facilities and infrastructure and conducts continuous supervision so that the community group can be established and independent.

Through the implementation of CSR community development, people will have skills and entrepreneurship, have access to markets and improve the economy. The community is trained to be creative and productive and be able to increase their income and ultimately social welfare and economic strengthening can be realized.

\section{RESEARCH METHODS}

In the preparation of this paper, the method used by the author is to use a qualitative descriptive method with literature studies. Information is obtained from books, journals, articles, lecture modules and the internet. In addition, writing is also done on the basis of observations and experiences of the author of the object of research, analysis of data, interpretation of the author, empirical experience and direct experience felt by the author while working at PLN for more than 27 years. Descriptive qualitative research methods aimed at describing and describing the phenomena that exist and emphasize the meaning of the results.

\section{RESULT AND DISCUSSION}

PLN is well aware that long-term business sustainability will not be realized only by meeting the operational and financial targets. Business objectives will be achieved if the Company is able to maintain a balance of economic, social and environmental performances.

The obtained economic value is eligible for the benefits of the community, the environment, employees and customers, through quality and sustainable social and environmental responsibility programs. The implementation of this program aims to have a positive impact directly or indirectly on all company stakeholders so as to create harmonious relationships to ensure long-term business sustainability.

The social responsibility program is implemented in an integrated manner with the application of the principles of good corporate governance. This is the principle of PLN's social responsibility program to not only prioritize the interests of the Shareholders, but also pay attention to the interests of all stakeholders. PLN is committed to taking a role as a driver of growth activities, community economic empowerment, and the creation of a harmonious relationship between the Company and the community, especially around the Company's operational areas. 
The implementation of CSR programs in accordance with the principles of GCG is part of the corporate culture. PLN's commitment in carrying out CSR programs in accordancewith the Corporate Ethics Standards (Code of Conduct) set out in the Directors' Decree.

\section{CSR Vision And MissionVision}

To place the PLN social and environmental responsibility programs at the forefront of increasing electricity needs while continuing to pay attention to the wellbeing of all stakeholders and the environment.

\section{Mission}

To carry out social activities to cover all the Company's stakeholders' interests so that they can bebound synergistically in order to improve the Company's image.

\section{Policy And Commitment Of Social Responsibility In Social And Community Development}

CSR strategies are always reviewed to adjust the company's vision and mission and are always refined by referring to Law No. 40 regarding Limited Liability Company article 74 Social and Environmental Responsibility, Government Regulation No.47 of 2012 concerning Corporate Social and Environmental Responsibility. To get an overview and at the same time formulate a priority scale of what is most needed by the community around PLN's assets, PLN conducts mapping and through discussions with stakeholdersto identify targets and social problems needed by the community.

The CSR program is PLN's obligation as a company that operates within the community and has the potential to cause environmental problems. In the construction of PLN's power plants and transmission lines, whose locations are spread throughout Indonesia, there are many obstacles that risk making the project completion schedule not timely. From the social aspect, the cause of the project was not completed on time was partly due to community resistance for various reasons. One of the Company's efforts to overcome social barriers is to approach and disseminate information to the local community by involving local government officials, community leaders and religious leaders. In addition, PLN through its CSR program and PKBL Program seeks to help the community to improve the quality of their economic life, education, and infrastructure facilities that they need.

Through the implementation of social responsibility programs, PLN is committed to contribute to supporting sustainable development goals including decent work and economic growth, as well as good health and well-being; building strong infrastructure, supporting inclusive industrialization and fostering innovation and ensuring sustainable consumption and production patterns; protect marine and terrestrial ecosystems; ensuring access to affordable, reliable, sustainable and modern energy for all.

The community around the company is one of the stakeholders who play an important role in the company's business continuity. CSR programs especially social and community development must provide tangible and sustainable benefits. PLN implements social and community development programs according to Law No. 40 regarding Limited Liability Companies listed in article 74 relating to Social and Environmental Responsibility and Government Regulation No.47 of 2012 concerning Corporate Social and Environmental Responsibility. In addition, ISO 26000 is also a reference for implementing corporate social responsibility programs, especially social and community development.

The triple bottom line concept (Planet, People, and Profit) is PLN's commitment in carrying out the Company's operational activities. With an awareness of social responsibility towards stakeholders and compliance with statutory regulations, PLN's commitment is contained in the Corporate Governance Guidelines. 
PLN's CSR program on social and community development was established after going through social mapping so that the activities carried out were right on target and in accordance with the main needs of the surrounding community. Social mapping is carried out in collaboration with the University and other Independent Institutions. Governments, NGOs, communities and other companies located around the PLN Unit are involved inthe process of developing community development programs which are subsequently included in the Strategic Plan and Work Plan. This way is done so that CSR programs can contribute to answering the needs and improving the welfare of the surrounding community.

Based on the results of social mapping and risk mapping, PLN sets the scope of its corporate social responsibility activities covering several fields such as education, health, economic, social, cultural, religious and environmental. Furthermore, PLN classifies corporate social responsibility programs into several typologies, namely Empowerment, Capacity Building, Infrastructure, and Charity.

\section{Activities And The Impacts}

1. Organic Integrated System (Ois) Program

Organic Integrated System is an organic agriculture program as a manifestation of PLN risk management, namely the view of the community that the distribution network of the Paiton Generation Unit through Very High Voltage Power Lines causes a reduction in agricultural productivity around the power plant. In addition, this program is esbtablished since there are issues in the community regarding dependence on Chemical fertilizer. The level of high dependence on chemical fertilizers causes scarcity of fertilizer; therefore, the price of fertilizer increases. This leads PLN's Paiton Generation Unit to conduct community development through the application of organic agriculture systems. The results for the community after theprogram is implemented, namely the existence of SUTET did not affect the productivity of agriculture at all around the Paiton Generation Unit. Agriculture productivity increased rapidly so as to boost the economy of farmers who were members of this program.

The impact of this program was not only for the community, but also for the PLN, specfically Paiton GU that achieved Gold PROPER from the Ministry of Environment and Forestry in 2017- 2018. PROPER is a Corporate Performance Assessment Program as one of the efforts of the Ministry of Environment to encourage company governance in environmental management.

2. Harmony Tourism Village

Harmony Binor Tourism Village Program is the result of the integrated program of Climate Resilience 'Posyandu' and Empowerment of Coastal Fishermen. The Location of the program was implemented in Binor Village, Paiton Sub-District, Probolinggo Regency by involving various groups which are female, fishers, PKK's female members, fishermen,Village Government, Tourism Agency, and Fisheries Service. The related issue is that the presence of coal fired power plants that cause damage to the ecosystem precisely in contrast to the maintenance of the environment in the Paiton GU area.

Binor village has an exotic underwater paradise. The location which is next to and near Paiton CFPP does not cause negative impact on marine biota. This isproven by the coral reef ecosystem which is sustainable. The fishes in Binor beach are also classified as massive and consist of Clown Fish, well known asNemo. These fishes are usually found in waters that have good corals. Wellmaintained ecosystems have a positive impact on fishermen as the availability of fish is sufficient so that they do not have to find fish in the middle of the sea. This also affects the operational costs of fishermen which become more economic. Other environmental issues arise due to the lack of 
awareness of clean sanitation from the community. The habit of defecating on the beach is a new issue.

This condition also changes after the community becomes aware of the cleanliness of the environment which is then provided additional income effects dueto tourist visits. The beneficiaries of this program are from various groups: the fishermen and PKK group. The fisherman group not only hunts fish but also untilizes boats for tourism. While the PKK group plays a role in the development of Postaklim through hydroponic plants sold in the coastal tourism area of Binor Harmoni.

3. Bawean Hijau Daun Ecotourism

Bawean Ecotourism is a CSR program with a sustainable empowerment approach in Desa Daun, Sangkapura, Gresik District. Ecotourism is a development program of activities to recover land affected by abrasion through planting and preservation of mangroves. In addition to improving public awareness about theimportance of preserving mangroves, they are also encouraged to be independent in terms of economy and health.

With the protection and improvement of the marine ecosystem, mangrove forests have become a tourist destination that has an impact on employment and increasing people's income.

4. Rumah Lipat Program (Sewing And Shellfish-Crafting House)

PLN establishes Rumah Lipat program which includes two types of activities, namely training in sewing and making handicrafts from green mussel shells. This program is implemented since there are many productive-age housewives who do not have permanent jobs to provide their own income. Rumah Lipat program is established with the consideration that sewing activities do not require a special place so that the women can stay at home to do household chores while making products from their sewing capabilities. This program is one form of risk management for social and economic gaps that can be created around the development unit.

Women who are active in sewing activities have been able to produce various products including clothing, bags, and pillows, opened clothing services and make clothes independently and have received personal orders. The handicrafts making from green mussel are chosen as they are abundant, but have not been utilizedoptimally. The entire program has an impact on environmental, economic, and socialaspects.

5. Pelag Mandiri Kampong

Pelag is located in Sukalilah Village, Sukaresmi Sub- District, Garut Regency with hilly topography. Cooperatives were established as a means of strengthening the economic institutions of the kampong. Pelag Village has agricultural potentials in plantation which are also developed under PLN Kamojang-Darajat's CSR Program. Java Preanger Arabica coffee is a rare coffee variety, which represents a coffeespecies that is Endemic in Pelag Kampong. At present, PLN Kamojang continues to develop the capabilities of Kampung Pelag coffee farmers by providing barista training and also focuses on processing coffee into ready-to-brew ground coffee. It is hoped that coffee farmers will be able to have higher selling prices for their coffee, thereby increasing the Pelag Kampong's economy

6. Bougenville Group Craft House

Bougenville Group Craft House is a program initiated by PLN Suralaya with the aim of expanding the sets of skills and income of housewives and reducingresidual landfill. Activities under this program include training, working capitalassistance, training and assistance in marketing the $3 R$ (reduce, reuse, recycle) products created by Bougenville Group

\section{CONCLUSION}

1. Corporate Social Responsibility is an act of the company as an effort to improve the 
welfare of the people. The paradigm shift in the business world is not only solely for profit, but also to be ethical and play a role in the creation of social investment.

2. Prioritized corporate CSR programs that have a positive impact in the form of improving the economic life of the community. Programs in the form of grants or assistance that are directly used up do not have an impact on improving the welfare of the community.

3. The company must conduct a comprehensive mapping of what is most needed by the targeted CSR program community. Thus, the people's economy can develop and improve independently so that one day CSR assistance can be diverted to other community development.

4. There is a need for a clear witness in addressing the issue of Corporate Social Responsibility By the applicable law so that in an effort to create the State's goal, namely people's welfare can be realized. There needs to be socialization related to the rule that Corporate Social Responsibility is an obligation of every company.

\section{REFERENCES}

Lako, Andreas. 2011. "Dekonstruksi CSR dan Reformasi Paradigma Bisnis dan Akuntansi”. Jakarta: Erlangga

Berampu, Adi Chandra. Agusta, Ivanovich. 2015. "Manfaat Partisipasi Masyarakat dalam Program Pengelolaan Sampah”. Jurnal Penyuluhan, Septeber 2015 Vol. 11 No. 2

Nurjihad, Fajar., Ali, Hapzi. 2020. "Etika Bisnis dan Implementasi Good Corporate Governance PT WijayaKarya”. [Online] Tersedia: https://www.academia.edu/41555972/ETIKA_BISNIS_DAN_IMPLEMENTASI_GOO D_CORPORATE_GOVERNANCE_PT.WIJAYA_KARYA_BUSINESS_ETHICS_A ND_IMPLEMENTATION_GOOD_CORPORATE_GOVERNANCE_PT.WIJAYA_K ARYA [14 Mei2020].

Kartini, Dwi. 2013. “Corporate Social Responsibility Transformasi Konsep Sustainibility Management dan Implementasi di Indonesia". Bandung: Refika Admita

Fitri, M. Rachman. Nurdizal, Asep, Efendi, dan Amir. 2015. "Panduan LengkapPelaksanaan CSR”. Jakarta: Penebar Swadaya

Kasali, Rhenald. 2007. “Manajemen Public Relation”. Jakarta. Ghalia Indonesia

Kartini, Dwi. 2013. "Corporate Social Responsibility Transformasi Konsep Sustainibility Management dan Implementasi di Indonesia". Bandung: Refika Admita

Annual Report PLN 2018. https://web.pln.co.id/statics/uploads/2019/11/PLN_SustainabilityReport-2018.pdf (28 Mei 2020, jam 20.00 WIB) 